\title{
Antimicrobial Activity of Stainless Steel with a Modified TiN Upperlayer on Meat Related Contaminants
}

\author{
Frédéric De Nardi ${ }^{1,4}$, David Delaunay ${ }^{1,2}$, Roland Talibart ${ }^{1},{\text { Xavier } \text { Castel }^{3} \text {, Laurent Le Gendre }}^{3}$, Arnaud Castillo ${ }^{1}$ \\ and Christine Pissavin ${ }^{1}$ \\ 1. IUT Saint-Brieuc-Université de Rennes 1, Département Génie Biologique, 18 rue Henri Wallon, Saint-Brieuc cedex 22004, \\ France \\ 2. Université de Rennes 1, ISCR, UMR CNRS 6226, 263 avenue du Général Leclerc, Rennes cedex 35042, France \\ 3. IUT de Saint-Brieuc-Université de Rennes 1, IETR, UMR-CNRS 6164, 18 rue Henri Wallon, Saint-Brieuc cedex 22004, France \\ 4. Université d'Angers, BNMI, UMR-CNRS 6214, rue Haute de Reculé, Angers 49045, France
}

\begin{abstract}
Advanced material with antibacterial properties would be a promising way to improve the disinfection process in food plants. Our objective was to combine the bactericidal effect of $\mathrm{TiO}_{2}$ with the mechanical strength of $\mathrm{TiN}$ coatings. A TiO $\mathrm{Tutile}_{2}$ film was obtained after annealing of a supplied 316 stainless steel with a TiN coating. This $\mathrm{TiO}_{2}$ upperlayer displays a photocatalytic activity under UV light exposure. The substrates with the $\mathrm{TiN}$ coating and the $\mathrm{TiO}_{2}$ upperlayer are more hydrophobic than the 316 control. The adhesion of either Listeria or Pseudomonas, on 316-TiN is characterized by the presence of clusters of cells, while the oxidation of the TiN surface leads to a more hydrophilic layer where cells are individualized. After UV illumination of the adherent cells and subsequent growth, the residual bacterial population present on 316- $\mathrm{TiO}_{2}$ is lower than that present on the 316-TiN. The bactericidal effect is more important on Listeria than on Pseudomonas.
\end{abstract}

Key words: Biofilm, Listeria, Pseudomonas, stainless steel, TiN, $\mathrm{TiO}_{2}$.

\section{Introduction}

Biofilms are the most abundant living form of bacteria found in animal, human body, plants, or on inert surface like stainless steel. In food manufacturing, biofilms containing pathogen bacteria are a recurrent economic and public health problem. Indeed, the occurrence of these biofilms in food-processing environments can cause post-processing contamination leading to lowered shelf-life of food products and transmission of food born infections [1, 2]. Most of the materials used in food plants, i.e. equipment, containers, are faced with the adhesion of bacteria. Among them, stainless steel is favourable for the development of microbial biofilms. Gounadaki and coworkers showed that most of the sampling sites tested (control points) were highly contaminated by

Corresponding author: Christine Pissavin, associate professor, research fied: microbiology. spoilage microbiota (i.e. Pseudomonadaceae, Enterobacteriaceae) ( $\left.>4 \log \mathrm{CFU} / \mathrm{cm}^{2}\right)$, with knives, cuttings, tables and mincing machines being the most heavily contaminated surfaces [3]. The pseudomonads are known to be pioneer colonizers of the surfaces that may condition the implantation of other bacteria. The presence of Listeria monocytogenes seems to be linked to that of Pseudomonas fragi in biofilms [4]. One strategy to fight these multispecies biofilms is to prevent microbial adhesion. In this way, several techniques were developed. Antimicrobial coatings and surface modifications are numerous like bactericidal releasing coatings containing silver or copper, bacteriophage-modified surface, polycationic (PEI) antimicrobials and light-activated antimicrobial agents $[5,6]$.

The photocatalytic activity of $\mathrm{TiO}_{2}$ (titanium dioxide) nanoparticles could be used as new process to improve the disinfection efficiency [7-9]. Indeed, 
illumination of $\mathrm{TiO}_{2}$ with UV light generates electrons in the conduction band which react with $\mathrm{O}_{2}$, and positive hole in the valence band which react with $\mathrm{HO}^{-}$or $\mathrm{H}_{2} \mathrm{O}$ to form Reactive Oxygen Species (ROS). ROS can damage cell membrane of bacteria as well as DNA [10]. The $\mathrm{TiO}_{2}$ thin films are elaborated by several methods as dip-coating (sol-gel process), reactive sputtering method, thermal oxidation and plasma treatment [11]. The $\mathrm{TiO}_{2}$ photocatalysis property is widely exploited to disinfect surface in medicine [12-14] and also for environmental applications in the development of coatings for destroying atmospheric pollutants such as nitrogen oxide gases [15]. Nevertheless, this property is less studied when associated with the stainless steels surface in food factories. A study has reported the anti-Listeria effect of $\mathrm{TiO}_{2}$ nanostructured thin film which was deposited on surfaces such as stainless steel and glass using the doctor blade technique [7]. TiN (titanium nitride) coating is already widely used in tools, dies and many mechanical parts to increase their lifetime and performance owing to its attractive properties such as hardness, reduced wear and chemical stability [16]. Nevertheless, TiN coating does not seem to limit a bacterial adhesion [17]. The objective of the work presented here was to combine the bactericidal effect of $\mathrm{TiO}_{2}$ to the mechanical strength of the TiN coating to limit contamination and improve cleanability of the open surfaces used in the food factories. The TiN coating grown on stainless steel substrates has been oxidized in a $\mathrm{TiO}_{2}$ upperlayer by thermal method $[18,19]$. The effect on the adhesion and the viability of Listeria monocytogenes and Pseudomonas fragi has been studied.

\section{Materials and Methods}

\subsection{Strains}

L. monocytogenes ECL 136 and P. fragi ECF 146 were coming from the Anses strain collection (HQPAP, Anses, Ploufragan, France). These strains were sampled on stainless steel surfaces from a poultry slaughterhouse [4].

\subsection{Coupon Preparation}

Bares of $0.5 \mathrm{~mm}$ thick AISI 316 stainless steel (316) (Goodfellow, France) and AISI 316 stainless steel with a $3 \mu \mathrm{m}$-thick TiN coating (316-TiN) (Goodfellow, France) were used as coupons. In order to grow $\mathrm{TiO}_{2}$ film on coupons, 316-TiN samples were oxidized in a hot air oven at $500{ }^{\circ} \mathrm{C}$ for $96 \mathrm{~h}\left(316-\mathrm{TiO}_{2}\right)$. All samples used are sized in $8 \mathrm{~mm} \times 8 \mathrm{~mm}$ coupons.

\subsection{Energy Dispersive X-ray Spectroscopy and X-ray Diffraction}

The chemical composition of the 316, 316-TiN and 316- $\mathrm{TiO}_{2}$ was carried out by Energy Dispersive X-ray Spectroscopy (EDX) (Microprobe Oxford, France) at $20 \mathrm{keV}$, prior to the sample preparation for adherent cells.

X-ray Diffraction (XRD) patterns were recorded with a diffractometer (Seifert 3003 PTS, France) in a $(\theta-2 \theta)$ parallel beam configuration. From a copper anticathode $(40 \mathrm{kV}, 40 \mathrm{kA})$, a parabolic multilayer and a Ge (220) monochromator, both mounted on the primary beam, reflected an intense and parallel beam of $\mathrm{K} \alpha 1$ radiation (with $1 / \mathrm{K} \alpha 1=0.154056 \mathrm{~nm}$ ). $2 \theta$ angle was swept from $10^{\circ}$ to $80^{\circ}$ by 0.01 steps. Each acquisition step lasted $4 \mathrm{~s}$ for a better signal-to-noise ratio.

\subsection{Roughness Measurements}

The roughness measurements $\left(\mathrm{R}_{\mathrm{MS}}\right)$ of the coupons were carried out by a rugosimeter (TR 2000 Time group Inc, France). The $\mathrm{R}_{\mathrm{MS}}$ value of a set of values is the square root of the arithmetic average of the squares of the original values. Average roughness values were determined from 10 surfaces of the 316 , 316-TiN and 316- $\mathrm{TiO}_{2}$ coupons.

\subsection{Wettability and Surface Energies}

Diiodomethane, water and formamide contact angles were determined in order to evaluate the 
surface energy characteristics of the 316, 316-TiN and 316- $\mathrm{TiO}_{2}$ coupons by the sessile drop technique, using a DGD Fast 60 goniometer coupled with the WinDrop++ software to capture and analyze the pictures (GBX Scientific Instruments, USA). The contact angle results are the mean value of three measurements at various positions on the coupon surface. Contact angles were converted to surface free energies using the Van Oss equation system [20].

Using the measured contact angle and considering the approach of Van Oss, it was possible to evaluate the surface characteristics of a solid according to its surface energy $\left(\gamma, \mathrm{mJ} / \mathrm{m}^{2}\right)$. The total surface energy of a solid $\left(\gamma_{\mathrm{S}}\right)$ is considered as the sum of an apolar Lifshitz-Van der Waals component $\left(\gamma_{\mathrm{LW}}\right)$ and an acid-base polar component $\left(\gamma_{\mathrm{AB}}\right)$ :

$$
\gamma_{\mathrm{S}}=\gamma_{\mathrm{LW}}+\gamma_{\mathrm{AB}}
$$

The acid-base component $\left(\gamma_{\mathrm{AB}}\right)$ consists in two non-additive parameters, one for the electron donor $\left(\gamma^{-}\right)$and one for the electron-acceptor $\left(\gamma^{+}\right)$as follows:

$$
\gamma_{\mathrm{AB}}=2\left(\gamma^{+} \times \bar{\gamma}\right)^{1 / 2}
$$

Contact angle values $(\alpha)$ can be related to the total surface energy and its components using simultaneously for the three reference liquids according to the equation below:

$$
\begin{gathered}
\gamma_{\mathrm{L}}(1+\cos \alpha)=2\left(\gamma_{\mathrm{S}}{ }^{\mathrm{LW}} \times \gamma_{\mathrm{L}}{ }^{\mathrm{LW}}\right)^{1 / 2}+ \\
\left(\gamma_{\mathrm{S}}{ }^{+} \times \gamma_{\mathrm{L}}{ }^{-}\right)^{1 / 2}+\left(\gamma_{\mathrm{L}}{ }^{+} \times \gamma_{\mathrm{S}}{ }^{-}\right)^{1 / 2}
\end{gathered}
$$

\subsection{Photocatalytic Activity}

The photocatalytic effect was evaluated by a methylene blue (MB) test [21] onto 316, 316-TiN (negative controls) and $316-\mathrm{TiO}_{2}$ coupons with a UV-C lamp (Microbial Safety hood PSM ESCO AC2-4S1, AES, France; $\lambda=254 \mathrm{~nm}, 360 \mathrm{~W}$ ) for $1 \mathrm{~h}$ at a distance of $2 \mathrm{~cm}$. Each coupon was placed inside the wells of a microplate and a volume of $50 \mu \mathrm{L}$ of $\mathrm{MB}$ solution at $0.002 \%(\mathrm{w} / \mathrm{v})$ was deposited on the surface of all coupons. After UV-C exposure, $950 \mu \mathrm{L}$ of saline water $\left(9 \mathrm{gL}^{-1} \mathrm{NaCl}\right)$ was added in each well and the absorbance was measured with a spectrophotometer (Thermospectronic, biomate ${ }_{3}$,
France) at $\lambda=650 \mathrm{~nm}$ (maximum absorption of the $\mathrm{MB})$. The variation of the optical density before and after UV-C exposure highlighted the photocatalytic activity on $316-\mathrm{TiO}_{2}$ in comparison with 316 and 316-TiN coupons.

Antimicrobial tests were performed to assess the photocatalytic activity towards bacteria. The opened wells of the microplate containing coupons covered with adherent bacteria, were exposed to a UV-C lamp for $20 \mathrm{~min}$ at $60 \mathrm{~cm}$. After rinsing, a drop of water was kept on each coupon. The photocatalytic activity was measured by the variability of bacteria viability on $316-\mathrm{TiO}_{2}$ in comparison with 316 and 316-TiN.

\subsection{Bacterial Adhesion and Viability}

Strains stored at $-80{ }^{\circ} \mathrm{C}$ were isolated on Brain Heart Infusion Agar plates (AES, France). After growth, one colony was taken and put in Tryptone Soy Broth (Biokar, France) complemented with Yeast extract at $6 \mathrm{gL}^{-1}$ (TSBYe), for $7 \mathrm{~h}$ at $25^{\circ} \mathrm{C}$. A second culture in TSBYe was performed to obtain cells in stationary growth state under the same conditions. The bacteria culture was centrifugated at $8,000 \mathrm{~g}$ for 10 min to remove the medium. The pellet was washed with one volume of saline solution $\left(9 \mathrm{gL}^{-1} \mathrm{NaCl}\right)$. Then, the cells were resuspended in saline water to obtain a suspension containing $10^{8}$ cells $\mathrm{mL}^{-1}$ according to the absorbance at $600 \mathrm{~nm}$. $50 \mu \mathrm{L}$ of this suspension were loaded onto the surface of each coupon. Then each coupon was placed in a well of a microplate inside a box containing moistened paper towels, to maintain wet atmosphere in order to avoid drying coupons. For bacterial adhesion, all coupons were incubated at $20{ }^{\circ} \mathrm{C}$ for $4 \mathrm{~h}$. After two rinsings with saline solution, coupons were placed in $1 \mathrm{~mL}$ of saline solution (9 $\mathrm{gL}^{-1} \mathrm{NaCl}$ ) to be sonicated for $10 \min$ at $47 \mathrm{kHz}$ (Ultrasonic Bath 3210, Branson, USA). Cultivable cells were enumerated on BHI plates after $24 \mathrm{~h}$ at $37^{\circ} \mathrm{C}$ for L. monocytogenes and $25^{\circ} \mathrm{C}$ for P. fragi.

After adhesion on the coupons $(4 \mathrm{~h})$, the cultivability of the cells was tested to assess the 
antibacterial properties of the material after photoactivation by UV. Coupons with adherent bacteria were immersed in $500 \mu \mathrm{L}$ of TSBYe diluted to $1 / 20^{\mathrm{e}}$ to provide some nutrients and to limit the detachment of bacteria [22]. Coupons were incubated at $20{ }^{\circ} \mathrm{C}$ for $19 \mathrm{~h}$ under the same conditions as previously described for adhesion. After bacterial growth, coupons were washed twice with $1 \mathrm{~mL}$ of saline solution before sonication and enumeration as previously described.

\subsection{Scanning Electron Microscopy}

Coupons with adherent cells were immersed in a $3 \%$ glutaraldehyde solution prepared in $0.1 \mathrm{M}$ phosphate buffer for $1 \mathrm{~h}$. After fixing, coupons were washed twice with saline water $\left(9 \mathrm{gL}^{-1} \mathrm{NaCl}\right)$ and passed down an ethanol gradient at $50 \%$ (10 min), $75 \%$ (10 min), 90\% (10 min) and $100 \%$ (10 min). The last step consisted to replace ethanol by a hexamethyl disilazane (HMDS) (Sigma-Aldrich, France) gradient at $50 \%(10 \mathrm{~min}), 75 \%(10 \mathrm{~min})$ and $100 \%(12 \mathrm{~h})$. The observations were realized with a Scanning Electron Microscope (SEM) (JEOL JSM 5600, France) operating at $10 \mathrm{keV}$.

\subsection{Statistical Analysis}

Statistical tests were carried out by using a two sample $t$-test with the same variance (XL Stats, free version, Addinsoft). Significant differences are indicated for each treatment $(p<0.05)$.

\section{Results}

\subsection{Physico-Chemical Characteristics of the Materials}

The chemical composition of the 316, 316-TiN and 316- $\mathrm{TiO}_{2}$ coupons was analyzed by EDX (Fig. 1). While no oxygen peak appeared on the spectra of 316 (Fig. 1A) and 316-TiN (Fig. 1B) coupons, atomic oxygen was detected on the 316-TiN coupon after its annealing at $500{ }^{\circ} \mathrm{C}$ for $96 \mathrm{~h}$ in air. The $\mathrm{O} / \mathrm{Ti}$ ratio, equal to 2 , would be representative of the growth of a $\mathrm{TiO}_{2}$ upperlayer on the TiN coating. As expected, the
$\mathrm{N} / \mathrm{Ti}$ ratio on $316-\mathrm{TiN}$ coupon is close to 1 (1.285 exactly). The "pearinteraction" of the incident electrons with the material being close to $1 \mu \mathrm{m}$ at 20 $\mathrm{keV}$, the detection of then itrogen atomic on the spectrum (Fig. 1C) would indicate the presence of a $\mathrm{TiO}_{2}$ layer with a thickness of slightly less than $1 \mu \mathrm{m}$. In order to demonstrate the presence of a $\mathrm{TiO}_{2}$ upperlayer, XRD patterns of the three kinds of coupons have been recorded (Fig. 2). A common feature

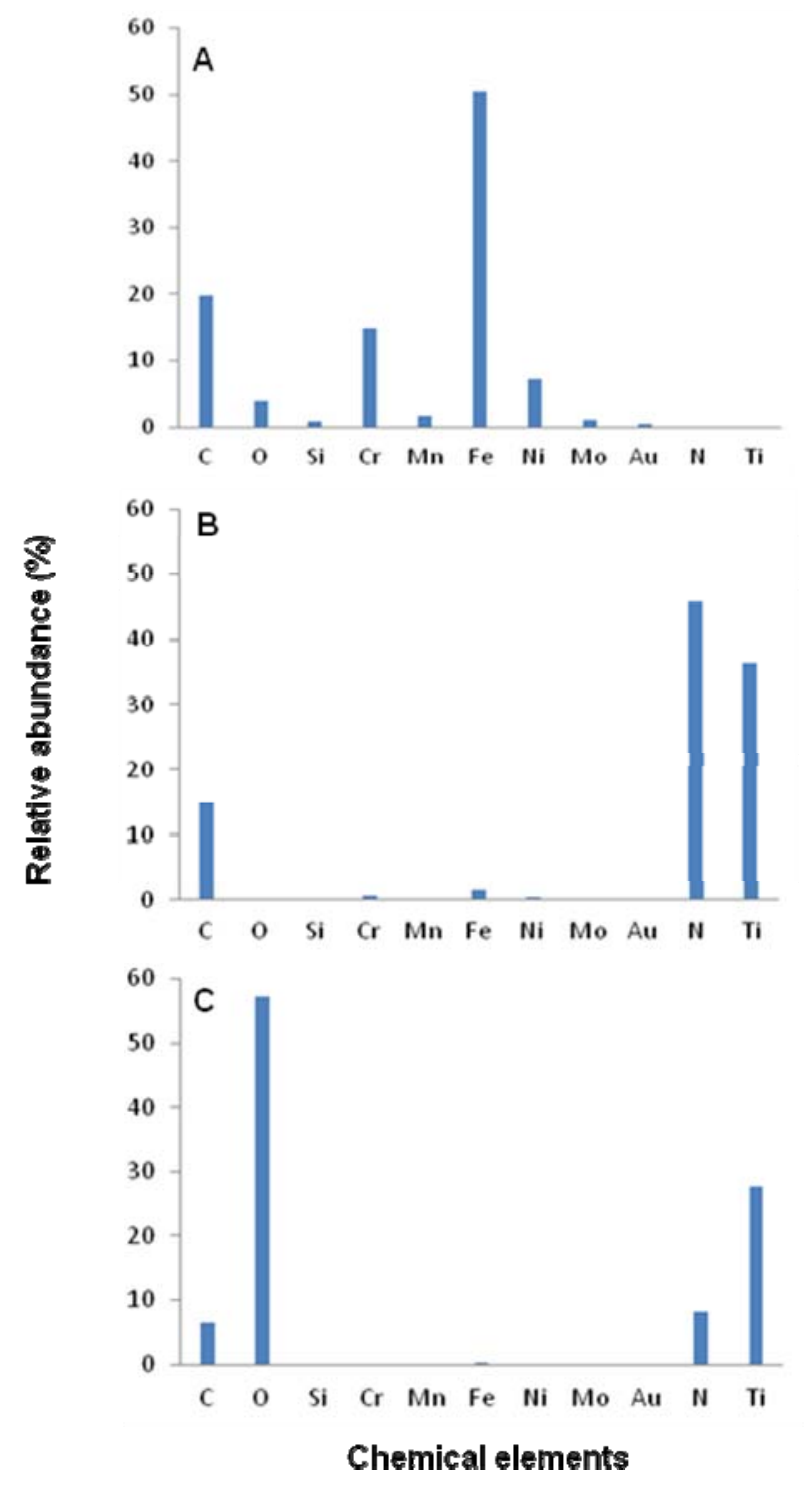

Fig. 1 Atomic abundance of the chemical elements detected by EDX analysis. (A) 316 stainless steel substrate (316), (B) $3 \mu \mathrm{m}$-thick TiN film coated on 316 stainless steel substrate (316-TiN), (C) $\mathrm{TiO}_{2}$ upperlayer $(\sim 1 \mu \mathrm{m})$ on $\mathrm{TiN}$ film coated on 316 stainless steel substrate $\left(316-\mathrm{TiO}_{2}\right)$. 


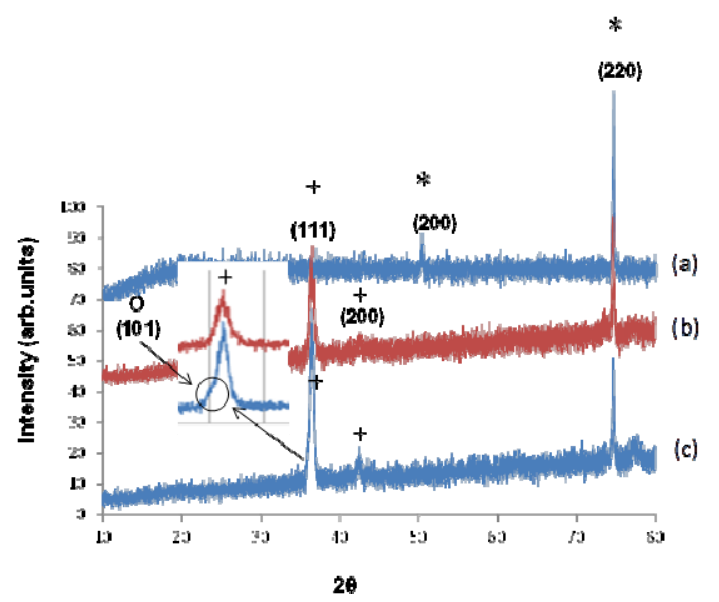

Fig. 2 XRD patterns of (a) 316 (b) 316-TiN (b) 316- $\mathrm{TiO}_{2}$. The peaks are related to $316(*), 316-\mathrm{TiN}(+), 316-\mathrm{TiO}_{2}(\mathrm{o})$.

in all XRD diagrams is the peak at $2 \theta=74.69^{\circ}$ which comes from the stainless steel 316 substrate $((220)$ peak in reference to the database JCPDS file 33-0397). The (200) peak is also present at $2 \theta=50.79^{\circ}$ on the diagram. The 316-TiN diagram exhibits the (111) and (200) peaks of the TiN coating (JCPDS file $38-1420$ ) at $2 \theta=36.66^{\circ}$ and $42.59^{\circ}$, respectively. After oxidation in air of the 316-TiN sample, a shoulder appears at $2 \theta=35.97^{\circ}$ on the (111) TiN peak (in inset). This shoulder is the signature of the (101) rutile plane of the $\mathrm{TiO}_{2}$ upperlayer (JCPDS file 77-0442).

The rugosity of the three kinds of coupons is similar. Indeed, the $\mathrm{R}_{\mathrm{MS}}$ was equal to $0.23 \pm 0.02 \mu \mathrm{m}$ for the 316 and $316-\mathrm{TiO}_{2}$ and $0.22 \pm 0.02 \mu \mathrm{m}$ for the $316-\mathrm{TiN}$ $(p>0.05)$.

The wettability and the surface energies were measured on the $316,316-\mathrm{TiN}$ and $316-\mathrm{TiO}_{2}$ coupons by using diiodomethane, water and formamide as solvents. The values are presented in Table 1. The contact angle measured with water showed that the
316-TiN was more hydrophobic $\left(85.6^{\circ} \pm 3.7^{\circ}\right)$ than the 316 coupon $\left(67.4^{\circ} \pm 2.7^{\circ}\right)$. However, the surface oxidation of the $\mathrm{TiN}$ coating in a $\mathrm{TiO}_{2}$ rutile upperlayer led to a decrease of the hydrophobicity since the angle decreased from $85.6^{\circ} \pm 3.7^{\circ}$ to $79.1^{\circ} \pm$ $4.1^{\circ}(p<0.05)$. Water and formamide were also used to reveal the electron acceptor/donor components thanks to their surface energy $(\gamma)$. The 316 stainless steel surface exhibits a higher electron-acceptor component $\left(\gamma+=0.58 \mathrm{~mJ} / \mathrm{m}^{2}\right)$ than 316-TiN $(\gamma+\sim 0$ $\left.\mathrm{mJ} / \mathrm{m}^{2}\right)$, but lower than $316-\mathrm{TiO}_{2}$ surface $(\gamma+=2.58$ $\mathrm{mJ} / \mathrm{m}^{2}$ ) (Table 1). For 316, 316-TiN and 316-TiO surfaces, the electron-donor component $\left(\gamma^{-}\right)$was equal to $5.11 \mathrm{~mJ} / \mathrm{m}^{2}, 4.60 \mathrm{~mJ} / \mathrm{m}^{2}$ and $1.16 \mathrm{~mJ} / \mathrm{m}^{2}$, respectively (Table 1 ).

The photocatalytic activity was evaluated by measuring the MB degradation (Fig. 3). A significant decrease of the absorbance of MB placed on the 316- $\mathrm{TiO}_{2}$ surface was observed at $650 \mathrm{~nm}$ in comparison with the 316 and 316-TiN $(p<0.001)$ (Fig. 3).

Table 1 Surface free-energy $\gamma\left(\mathrm{mJ} / \mathrm{m}^{2}\right)$ broken down as apolar lipshitz-van der waals $\gamma_{\mathrm{lw}}$ component and acid-base polar $\gamma_{\mathrm{ab}}$ component with the electron-donating $\gamma$ - and the electron-accepting $\gamma+$ parameters were measured. Standard deviations $( \pm$ ) were determined over three separate measures.

\begin{tabular}{llllllll}
\hline & $\begin{array}{l}\text { Diiodomethane } \\
\left({ }^{\circ}\right)\end{array}$ & $\begin{array}{l}\text { water } \\
\left({ }^{\circ}\right)\end{array}$ & $\begin{array}{l}\text { Formamide } \\
\left({ }^{\circ}\right)\end{array}$ & $\begin{array}{l}\gamma \\
\left(\mathrm{mJ} / \mathrm{m}^{2}\right)\end{array}$ & $\begin{array}{l}\gamma_{\mathrm{LW}} \\
\left(\mathrm{mJ} / \mathrm{m}^{2}\right)\end{array}$ & $\begin{array}{l}\gamma_{+} \\
\left(\mathrm{mJ} / \mathrm{m}^{2}\right)\end{array}$ & $\begin{array}{l}\gamma- \\
\left(\mathrm{mJ} / \mathrm{m}^{2}\right)\end{array}$ \\
\hline 316 & $38.1 \pm 1.3$ & $67.4 \pm 2.7$ & $49.1 \pm 1.9$ & 46.51 & 40.55 & 0.58 & 5.11 \\
$316-\mathrm{TiN}^{2}$ & $43.6 \pm 1.1$ & $85.6 \pm 3.7$ & $64.9 \pm 3.1$ & 37.99 & 37.80 & 0.00 & 4.60 \\
$316-\mathrm{TiO}_{2}$ & $39.2 \pm 3.8$ & $79.1 \pm 4.1$ & $40.1 \pm 1.8$ & 45.63 & 39.93 & 2.58 & 1.16 \\
\hline
\end{tabular}




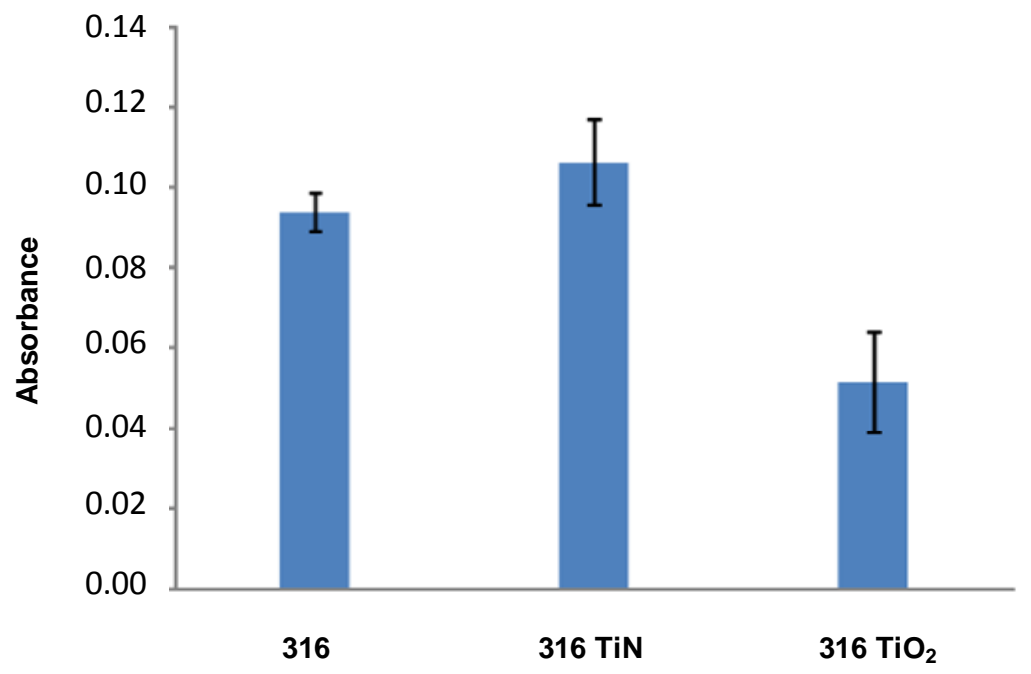

Fig. 3 Variation of the absorbance of the methylene blue (MB) loaded on 316, 316-TiN and 316-TiO 2 coupons after UV-C exposure for $1 \mathrm{~h}$.
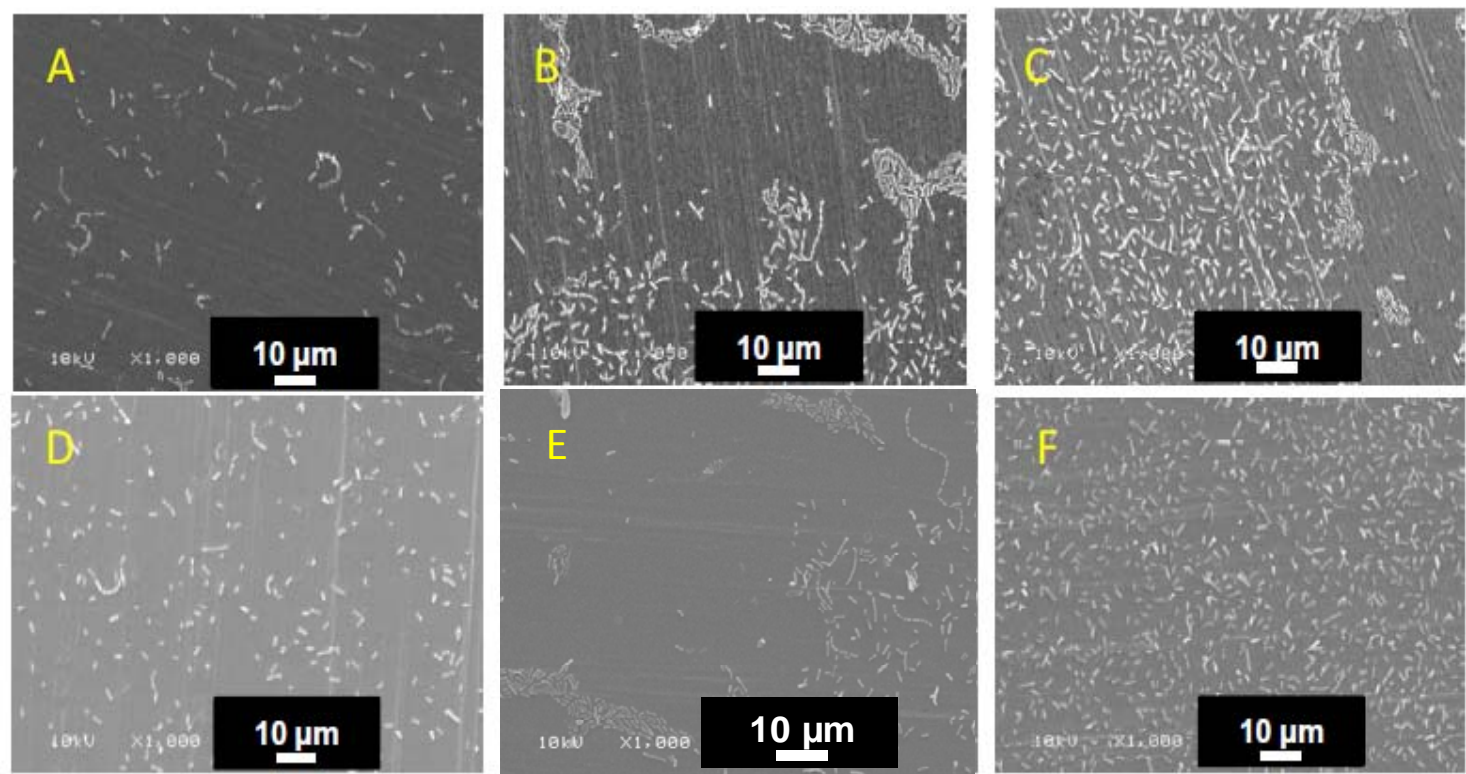

Fig. 4 SEM observations of the adherent cells of $P$. fragi after 4 hours on (A) 316, (B) 316-TiN, (C) 316-TiO ${ }_{2}$ and, with UV-C exposure during an additional time of $20 \mathrm{~min}$ on (D) 316, (E) 316-TiN, (F) 316-TiO.

\subsection{Adhesion of Bacterial Cells}

The organization of the adherent cells of either $P$. fragi or L. monocytogenes onto 316, 316-TiN and 316- $\mathrm{TiO}_{2}$ coupons was observed by SEM after $4 \mathrm{~h}$ of contact (Figs. 4 and 5). Some differences were noticed according to the support. Indeed, single cells were observed on 316 stainless steel coupons for both Listeria and Pseudomonas strains. On 316-TiN coupons, some clusters of cells, that may reach up to 50 cells, were observed for Listeria (Fig. 5) whereas the clusters were smaller for Pseudomonas strains (Fig. 4). More individual cells were present on the 316- $-\mathrm{TiO}_{2}$ for the both strains.

The number of cultivable adherent cells was similar on 316-TiN and 316 coupons (Fig. 6). Nevertheless, the Pseudomonas cells were significantly less numerous on $316-\mathrm{TiO}_{2}$, than on either 316 or $316-\mathrm{TiN}$ coupons $(p<0.05)$. For the Listeria strain, no difference between the number of cells on 316, 316-TiN, and $316 \mathrm{TiO}_{2}$ was observed (Fig. 6). 

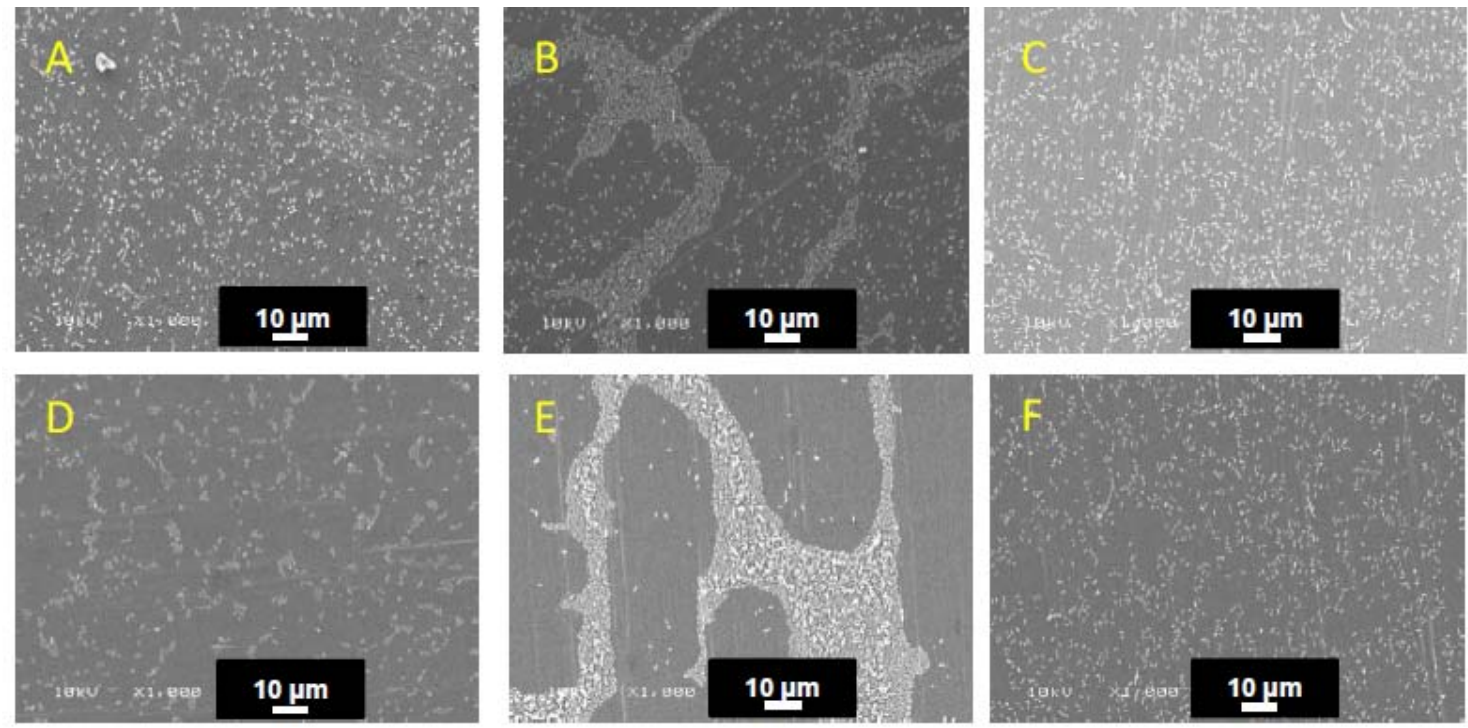

Fig. 5 SEM observations of the adherent cells of $L$. monocytogenes after 4 hours on (A) 316, (B) 316-TiN, (C) 316-TiO 2 and, with UV-C exposure during an additional time of $20 \mathrm{~min}$ on (D) 316, (E) 316-TiN, (F) 316-TiO 2

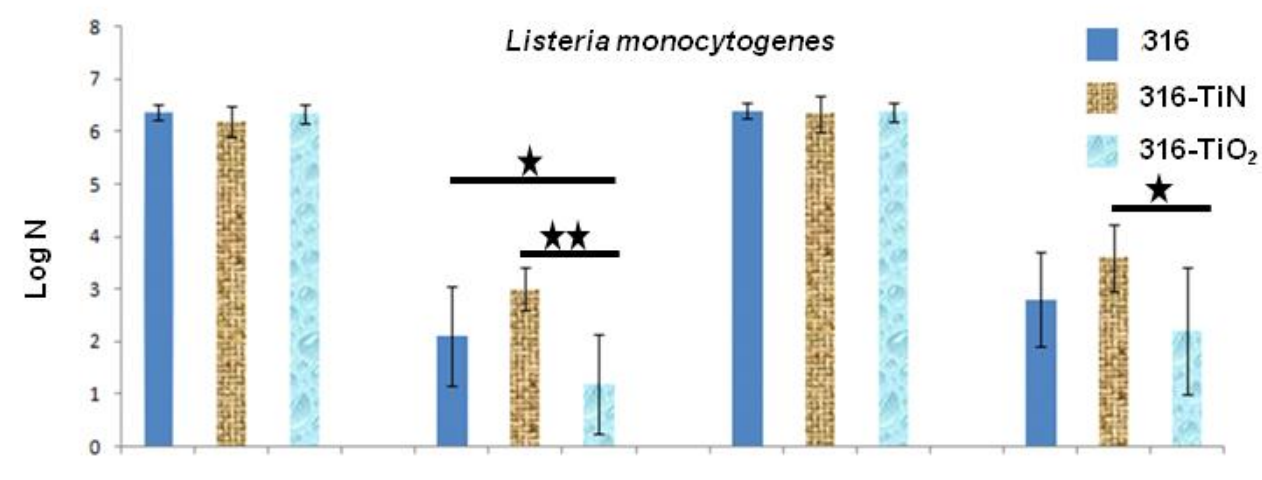

Adhesion (4 h)

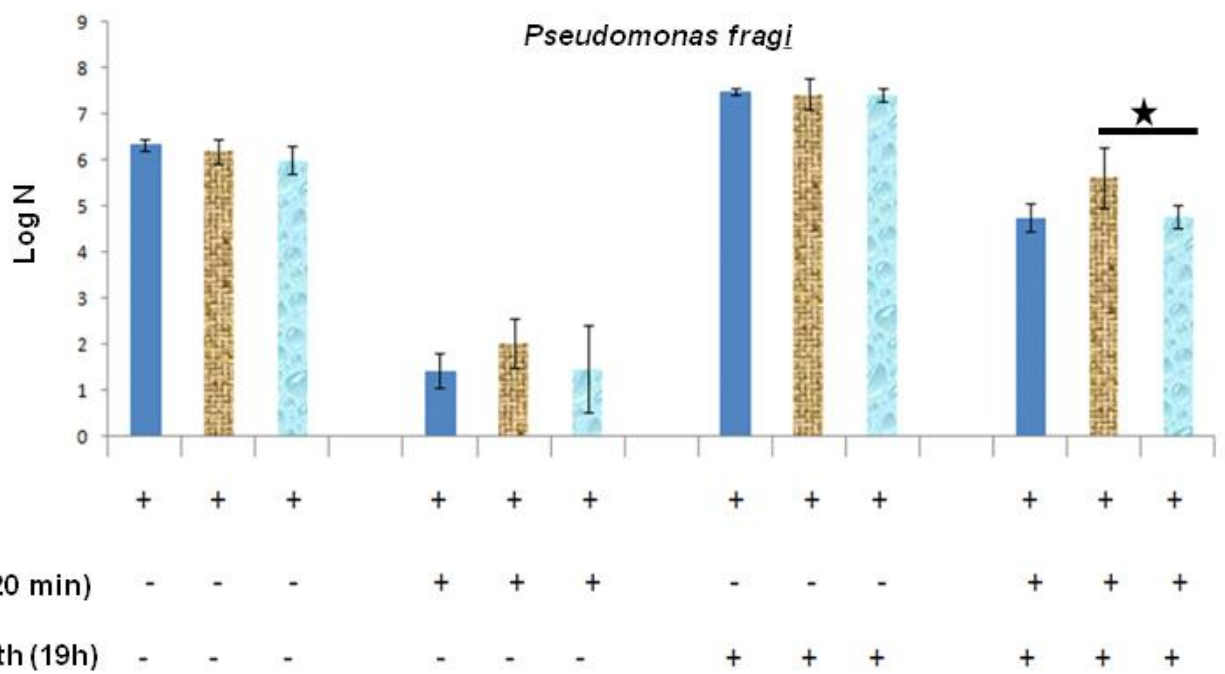

Fig. 6 Antibacterial activity of 316, 316-TiN and 316- $\mathrm{TiO}_{2}$ coupons on adherent $L$. monocytogenes and $P$. fragi cells. Log (N) with $\mathrm{N}$ corresponding to the concentration of cultivable bacteria $\left(\mathrm{CFU} \cdot \mathrm{mL}^{-1}\right)$. (+) and (-) indicate if the following conditions have occurred or not: after a $4 \mathrm{~h}$ adhesion step, the coupons were washed with saline water. They were submitted or not to UV-C light for $20 \mathrm{~min}$. The bacteria were grown during $19 \mathrm{~h}$ additional hours or not. Black stars indicate significant difference $(n=9)$. 
The UV-C exposure of the $316-\mathrm{TiO}_{2}$ with adherent cells, led to a dispersion of the Pseudomonas cells (Fig. 4) while no change was observed for Listeria (Fig. 5).

\subsection{Bactericidal Effect}

Without UV-C light treatment, the number of adherent bacteria was the same whatever the kind of coupons except for Pseudomonas on 316- $\mathrm{TiO}_{2}$ surface where adherent bacteria was slightly less numerous (Fig. 6). As also shown in Fig. 6, the effects of the
UV-C light treatment were more important on Pseudomonas viability loaded on 316 and 316-TiN coupons than on Listeria $(p<0.05, n=9)$ ). After UV-C exposure, considering the number of remaining adherent cultivable cells, no significant difference was observed between the three kinds of coupons with Pseudomonas ( $p>0.05, n=9$ ). Less remaining adherent Listeria on $316-\mathrm{TiO}_{2}$ was observed compared to the 316-TiN coupon ( $p<0.05, n=9$ ).

The development of the adherent cells on each kind of materials was studied by enumeration of the cultivable

UV

316-TiN

$316-\mathrm{TiO}_{2}$
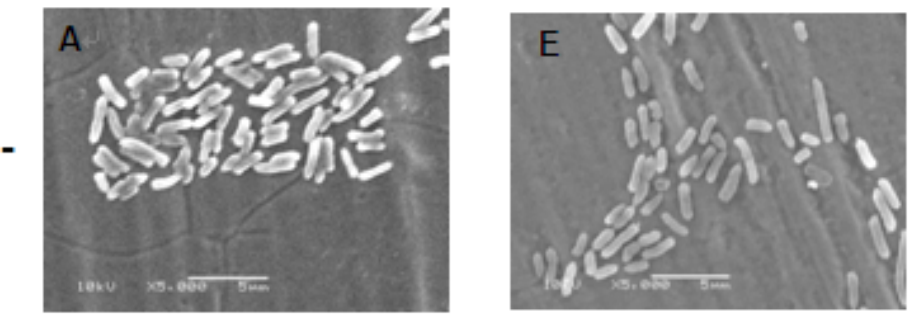

\section{P. fragi}
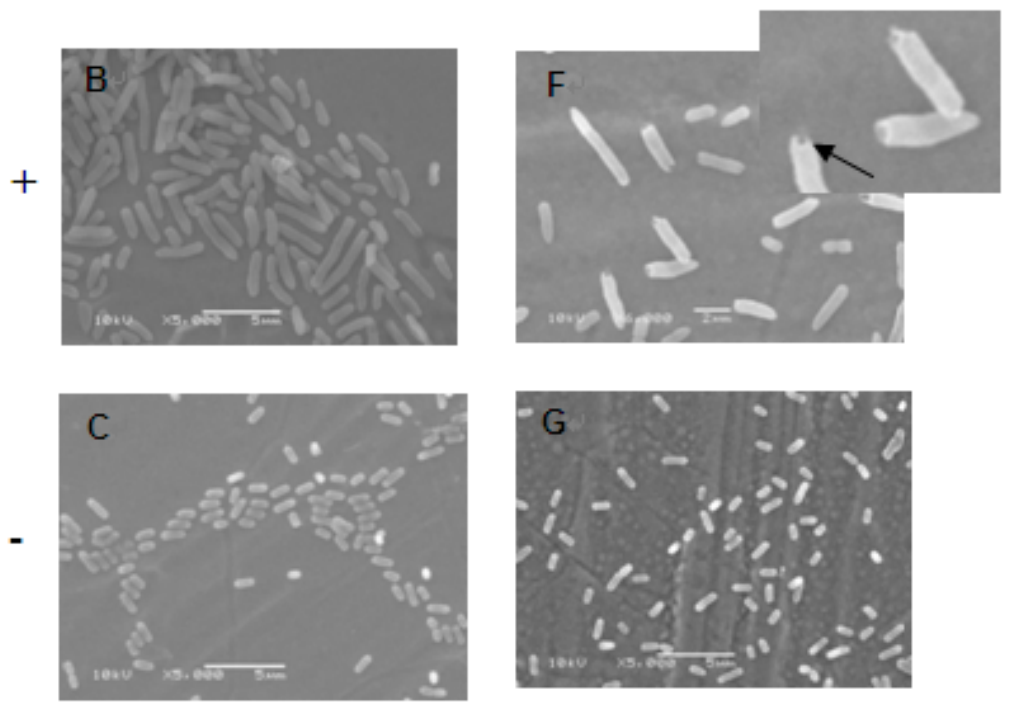

\section{L. monocytogenes}
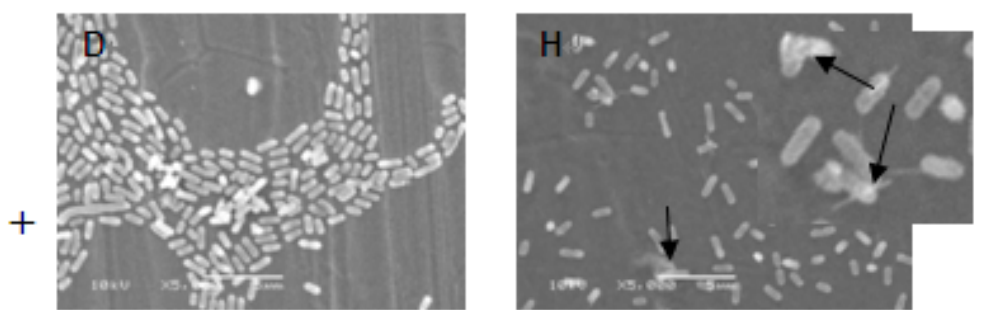

Fig. 7 SEM observations of $P$. fragi and L. monocytogenes cells adhered for 4 hours on 316-TiN (A to D) and 316-TiO 2 (E to G) coupons, before (A, C, E, G) and after (B, D, F, H) UV-C treatment (20 min). The arrows indicate bacteria damage. 
ones after $19 \mathrm{~h}$ following the UV-C treatment (Fig. 6). The same experiment was performed without UV-C treatment as a standard. In this latter case, Listeria and Pseudomonas colonized all the supports with the same extend. But, after UV-C exposure, more bacteria were numbered on 316-TiN than on the standard 316 coupons $(p<0.05)$. There were more viable Listeria and Pseudomonas bacteria on 316-TiN coupons after UV-C treatment. For the 316- $\mathrm{TiO}_{2}$ coupons, a decrease of the number of adherent cells was observed compared to the 316-TiN coupons. Indeed, Listeria developed cells were almost 2 log less numerous than on 316-TiN coupons $(p<0.05)$ and the cells of Pseudomonas were almost 1 log less numerous on $316-\mathrm{TiO}_{2}$ than on 316-TiN $(p<0.05)$. The difference in the number of cultivable bacteria between 316 and 316- $\mathrm{TiO}_{2}$ coupons was similar to the adhesion followed to UV-C exposure steps.

The damages relevant to the photocatalytic action of the $\mathrm{TiO}_{2}$ upperlayer were observed in Fig. 7. The most notable effect on Pseudomonas cells was located at the apical end. For Listeria, altered membranes and a cytoplasm release were observed. Moreover, some broken pili were noticed.

\section{Discussion}

The attachment of foodborne bacteria onto open surfaces and the formation of biofilms in meat processing environments are a recurrent source of cross contamination [23]. Some control strategies are based on the use of hot water, biocides, antimicrobial compounds and/or on the improvement of the cleanability of the equipment. In the meat plants, the knives are likely contaminated by bacteria. During the process, the Health Regulation recommends their treatment with $82{ }^{\circ} \mathrm{C}$ hot water. Nevertheless, these operations: (1) present some risk of operator injury through scalding, (2) are energy and water consumers, and (3) induce fogging and condensation formation [24]. Some authors suggest to decrease the temperature of the water bath and to add antimicrobials, such as lactic acid [24, 25]. However, these procedures lead to a potential bacterial load in the water baths over the time. A sterilization step concerns the knives sterilization after their work period, under UV irradiation.

The objective of this work was to combine the bactericidal effect of the photoactivable $\mathrm{TiO}_{2}$ material to the mechanical strength of the TiN coating to limit the growth of the meat related contaminants onto the blades. TiN is known to be a hard material with a low friction wear, used as resistant coating deposited on cutting and forming tools [17]. A thin layer of $\mathrm{TiO}_{2}$ was obtained by thermal treatment of a TiN upperlayer deposited on stainless steel. As shown by EDX and XRD analyses, it was a $\mathrm{TiO}_{2}$ rutile upperlayer with a thickness close to $1 \mu \mathrm{m}$. This $\mathrm{TiO}_{2}$ phase is more thermodynamically stable than the $\mathrm{TiO}_{2}$ anatase phase, nonetheless with a lower photocatalytic activity [26]. Indeed, the $316-\mathrm{TiO}_{2}$ coupons displayed a photocatalytic activity due to the production of ROS [27].

The oxidation of the TiN coating has not changed the sample surface roughness but it has modified the wettability and the surface energy of the coupons. The 316- $\mathrm{TiO}_{2}$ surface is more hydrophilic than that of the 316-TiN coupons and more hydrophobic than that of the 316 coupons. The acid-base polar component $\gamma_{\mathrm{AB}}$ was higher with the $316-\mathrm{TiO}_{2}$ upperlayer $\left(5.99 \mathrm{~mJ} / \mathrm{m}^{2}\right)$ than with $316-\mathrm{TiN}$ coating $\left(0.24 \mathrm{~mJ} / \mathrm{m}^{2}\right)$. These parameters are important, since it is well established that bio-adhesion and fouling are conditioned by several surface properties, such as roughness, surface composition, electrostatic charges, wettability and surface energy [12, 28, 29].

Despite the difference of wettability and surface energy between the coated or the bare stainless steel coupons, no significant difference in the attached cell number was observed for the three types of support $(p>0.05)$. In consequence, the oxidation of TiN to form $\mathrm{TiO}_{2}$ did not provide any anti-fouling property to the material. These results are in accordance with 
previous studies showing no significant difference concerning the adhesion of L. monocytogenes strains onto TiN coating [17] or onto $\mathrm{TiO}_{2}$ coating without UV activation [7], in comparison with stainless steel. However, the organization of the adhered cells observed by SEM was not identical for the whole coupons (Figs. 4 and 5). Pseudomonas and Listeria cells were organized in clusters onto 316-TiN coupons, while individualized cells were observed onto 316 and 316- $\mathrm{TiO}_{2}$ coupons (Figs. 4, 5 and 7). These results could be explained by the greater hydrophobicity of the 316-TiN surface, than that of the 316 and 316- $\mathrm{TiO}_{2}$ surfaces (Table 1).

For Pseudomonas, only few clusters were observed and a lot of individual cells were detected (Figs. 4 and 7). This may be explained by the switch of the electron donating/accepting property of the TiN upperlayer $\left(g^{+}=0.00 \mathrm{~mJ} / \mathrm{m}^{2}, g^{-}=4.60 \mathrm{~mJ} / \mathrm{m}^{2}\right)$ after its partial oxidation in $\mathrm{TiO}_{2}\left(g^{+}=2.58 \mathrm{~mJ} / \mathrm{m}^{2}, g^{-}=\right.$ $1.16 \mathrm{~mJ} / \mathrm{m}^{2}$ ).

After UV C illumination, neither 316 nor 316-TiN coupons displayed any other bactericidal activity than those induced by germicidal UV radiations. The UV treatment exerts a microbial effect by subsequent mutagenesis of the cell DNA [30, 31]. On the 316 standard coupons, adherent cells of Pseudomonas were more sensitive to the bactericidal effect of the UV than those of Listeria. This result is in accordance with an another study that showed a more pronounced sensitivity of Gram - bacteria to UV than the Gram + ones [32]. However, when adhered to the 316-TiN surfaces, the cells of either Pseudomonas or Listeria tended to be less sensitive to the UV treatment than those adhered on the 316 surfaces. This difference did not seem to be significant. This may be related to the cell organization in cluster that may protect them toward the mutagenic effect of the UV radiations.

The UV illumination of the $316-\mathrm{TiO}_{2}$ surfaces induced higher decrease of the number of cultivable cells, compared with that of the 316-TiN surfaces, whatever the strain tested. This behavior could arise from two properties of the $\mathrm{TiO}_{2}$ surfaces acquired after their photoactivation by UV, i.e. superhydrophily and ROS production [33]. The action of the UV light on the $\mathrm{TiO}_{2}$ material generates an electron/hole pair and subsequent the $\mathrm{TiOH}$ formation in the presence of water molecules [33, 34]. The Pseudomonas cells appeared more dispersed (Figs. 4 and 7) as a result of a modification in the $\mathrm{TiO}_{2}$ wettability after UV treatment.

According to the enumeration of viable bacteria, Listeria appeared to be more sensitive to the photocatalytic effect than Pseudomonas (Fig. 6). The produced ROS caused membrane damages at the apical ends of the Pseudomonas cells (Fig. 7). This was already observed for E. coli cells [35]. For Listeria, adherent cells onto $\mathrm{TiO}_{2}$ have broken their flagella and the cytoplasm is released (Fig. 7). This result is in accordance with a previous study demonstrating that ROS causes cell damages, membrane peroxidation, DNA breakage [36, 37].

The bactericidal effect of the UV photoactivated 316- $\mathrm{TiO}_{2}$ surface restricted the bacterial load. Indeed, after UV treatment and subsequent growth, the population of alive bacteria was less important onto 316- $\mathrm{TiO}_{2}$ than onto 316-TiN (Fig. 6).

Verran and coworkers demonstrated that coating stainless steel with titanium may increase the hygienic properties because of the easier removal of both $E$. coli cells and meat conditioning films [38]. In our work, a $\mathrm{TiO}_{2}$ coating obtained by the partial oxidation of a TiN layer deposited on stainless steel substrate is sufficient to take advantage of a photocatalytic activity with an antibacterial effect, in addition to the hardness properties of the layer. It is an easy and low cost effective process to produce equipment with antimicrobial properties. The photocatalytic activity can even be increased through the optimisation of the oxidation parameters. This could be efficient to fight against meat related contaminants including pathogen bacteria. Indeed, the inactivation of pathogenic bacteria, e.g. Escherichia coli O157:H7, L. 
monocytogenes and Salmonella Typhimurium, in a liquid culture by UV-assisted $\mathrm{TiO}_{2}$-photocatalytic was demonstrated [36]. The sterilisation time in UV-sterilizers may be shortened thanks to the presence of the photoactivable layer and the resulting cumulative and synergistic effect of UV and ROS.

\section{Acknowledgments}

This work was supported by grants from the Technical University Institute of Saint-Brieuc. We thank the members of the HQPAP unit of Anses for the strains and Anthony Picard for helpful laboratory work and discussions.

\section{References}

[1] Flint, S. H., Bremer, P. J., and Brooks, J. D. 1997. "Biofilms in Dairy Manufacturing Plant Description, Current Concerns and Methods of Control." Biofouling 11 (1): 81-97.

[2] Carpentier, B., and Cerf, O. 2011. "Review-Persistence of Listeria Monocytogenes in Food Industry Equipment and Premises.” Int. J. Food Microbiol 145: 1-8.

[3] Gounadaki, A. S., Skandamis, P. N., Drosinos, E. H., and Nychas, G. J. 2008. "Microbial Ecology of Food Contact Surfaces and Products of Small-Scale Facilities Producing Traditional Sausages." Food Microbiol 25 (2): 313-23.

[4] Chasseignaux, E., Gerault, P., Toquin, M. T., Salvat, G., Colin, P., and Ermel, G. 2002. "Ecology of Listeria Monocytogenes in the Environment of Raw Poultry Meat and Raw Pork Meat Processing Plants." FEMS Microbiol Lett 210 (2): 271-5.

[5] Page, K., Wilson, M., and Parkin, I. P. 2009. "Antimicrobial Surfaces and Their Potential in Reducing the Role of the Inanimate Environment in the Incidence of Hospital-Acquired Infections." J. Mater. Chem. 19: 3819-31.

[6] Dunnill, C. W., Page, K., Aiken, Z. A., Noimark, S., Hyett, G., and Kafilzas, A. 2011. "Nanoparticulate Silver Coated-Titania Thin Films-Photo-Oxidative Destruction of Stearic Acid under Different Light Sources and Antimicrobial Effects under Hospital Lighting Conditions." Journal of Photochemistry and Photobiology A: Chemistry 220: 113-23.

[7] Chorianopoulos, N. G., Tsoukleris, D. S., Panagou, E. Z., Falaras, P., and Nychas, G. J. 2011. "Use of Titanium Dioxide $\left(\mathrm{TiO}_{2}\right)$ Photocatalysts as Alternative Means for Listeria Monocytogenes Biofilm Disinfection in Food
Processing." Food Microbiol 28 (1): 164-70.

[8] Frojd, V., Linderback, P., Wennerberg, A., Chavez de Paz, L., Svensater, G., and Davies, J. R. 2011. "Effect of Nanoporous $\mathrm{TiO}_{2}$ Coating and Anodized $\mathrm{Ca}^{2+}$ Modification of Titanium Surfaces on Early Microbial Biofilm Formation." BMC Oral Health 11: 8.

[9] Hiura, T., Koseki, H., Shiraishi, K., Asahara, T., Tsurumoto, T., and Shindo, H. 2010. "Photocatalytic $\mathrm{TiO}_{2}$ Particles Confer Superior Antibacterial Effects in A Nutrition-Rich Environment: An in Vitro Study.” Biomed Res. 31: 151-4.

[10] Gogniat, G., Thyssen, M., Denis, M., Pulgarin, C., and Dukan, S. 2006. "The Bactericidal Effect of $\mathrm{TiO}_{2}$ Photocatalysis Involves Adsorption onto Catalyst and the Loss of Membrane Integrity.” FEMS Microbiol Lett. 258 (1): 18-24.

[11] Egerton, T. A., Kosa, S. A., and Christensen, P. A. 2006. "Photoelectrocatalytic Disinfection of E. coli Suspensions by Iron Doped $\mathrm{TiO}_{2}$." Physical Chemistry Chemical Physics 8: 398-406.

[12] Jeyachandran, Y. L., Venkatachalam, S., Karunagaran, B., Narayanandass, S. K., Mangalaraj, D., and Bao, C. Y. 2007. "Bacterial Adhesion Studies on Titanium, Titanium Nitride and Modified Hydroxyapatite Thin Films." Materials Science and Engineering 27: 35-41.

[13] Lin, H., Xu, Z., Wang, X., Long, J., Su, W., and Fu, X. 2008. "Photocatalytic and Antibacterial Properties of Medical-Grade PVC Material Coated with $\mathrm{TiO}_{2}$ Film." J Biomed Mater Res B Appl. Biomater 87: 425-31.

[14] Tsuang, Y. H., Sun, J. S., Huang, Y. C., Lu, C. H., Chang, W. H., and Wang, C. C. 2008. "Studies of Photokilling of Bacteria Using Titanium Dioxide Nanoparticles." Artif Organs 32: 167-74.

[15] Allen, N. S., Edge, M., Sandoval, G., Verran, J., Stratton, J., and Maltby, J. 2005. "Photocatalytic Coatings for Environmental Applications." Photochem. Photobiol. 81: 279-90.

[16] Yoon, S. Y., Lee, K. O., and Kim, K. H. 2002. "Comparison for Mechanical Properties between TiN and TiAlN Coating Layers by AIP Technique." Journal of Materials Processing Technolog 130 (131): 260-5.

[17] Skovager, A., Whitehead, K., Wickens, D., Verran, J., Ingmer, H., and Arneborg, N. 2013. "A Comparative Study of Fine Polished Stainless Steel, TiN and TiN/Ag Surfaces: Adhesion and Attachment Strength of Listeria Monocytogenes as Well as Anti-listerial Effect." Colloids Surf B Biointerfaces 109: 190-6.

[18] Polyakova, G., and Hübert, T. 2001. "Thermal Stability of TiN Thin Films Investigated by DTG/DTA.” Surface and Coatings Technology 141 (1): 55-61.

[19] Zhu, L., Xie, J., Cui, X., Shen, J., Yang, X., and Zhang, Z. 2010. "Photoelectrochemical and Optical Properties of 
N-doped $\mathrm{TiO}_{2}$ Thin Films Prepared by Oxidation of Sputtered Tinx Films." Vacuum 84: 797-802.

[20] Van Oss, C. J. 1996. Forces Interfaciales En Milieux Aqueux. Paris.

[21] Fu, P., Luan, Y., and Dai, X. 2004. "Preparation of Activated Carbon Fibers Supported $\mathrm{TiO}_{2}$ Photocatalyst and Evaluation of Its Photocatalytic Reactivity.” Journal of Molecular Catalysis A: Chemical 221: 81-8.

[22] Leriche, V., Briandet, R., and Carpentier, B. 2003. "Ecology of Mixed Biofilms Subjected Daily to A Chlorinated Alkaline Solution: Spatial Distribution of Bacterial Species Suggests a Protective Effect of One Species to Another." Environ Microbiol 5 (1): 64-71.

[23] Giaouris, E., Heir, E., Hebraud, M., Chorianopoulos, N., Langsrud, S., and Moretro, T. 2014. "Attachment and Biofilm Formation by Foodborne Bacteria in Meat Processing Environments: Causes, Implications, Role of Bacterial Interactions and Control by Alternative Novel Methods." Meat Sci. 97 (3): 298-309.

[24] Leps, J., Einschutz, K., Langkabel, N., and Fries, R. 2013. "Efficacy of Knife Disinfection Techniques in Meat Processing." Meat Sci. 95 (2): 185-9.

[25] Eustace, I., Midgley, J., Giarrusso, C., Laurent, C., Jenson, I., and Sumner, J. 2007. “An Alternative Process for Cleaning Knives Used on Meat Slaughter Floors." Int. J. Food Microbiol 113 (1): 23-7.

[26] Hanaor, D. A. H., and Sorell, C. C. 2011. "Review of the Anatase to Rutile Phase Transformation." Journal of Materials Science 46: 855-74.

[27] Benabbou, A. K., Derriche, Z., Felix, C., Lejeune, P., and Guillard, C. 2007. "Photocatalytic Inactivation of Escherichia Coli Effect of Concentration of $\mathrm{TiO}_{2}$ and Microorganism, Nature, and Intensity of UV Irradiation.” Applied Catalysis B: Environmental 76: 257-63.

[28] Flint, S. H., Bremer, P. J., and Brooks, J. D. 2000. "Properties of the Stainless Steel Substrate, Influencing the Adhesion of Thermo-Resistant Sreptococci." Journal of Food Engineering 43: 235-42.

[29] Briandet, R., Herry, J., and Bellon-Fontaine, M. 2001. "Determination of the Van der Waals, Electron Donor and Electron Acceptor Surface Tension Components of
Static Gram-Positive Microbial Biofilms." Colloids Surf B. Biointerfaces 21 (4): 299-310.

[30] Yang, X., and Wang, Y. 2008. "Photocatalytic Effect on Plasmid DNA Damage under Different UV Irradiation Time." Build Environ 43: 253-7.

[31] Foster, H. A., Ditta, I. B., Varghese, S., and Steele, A. 2011. "Photocatalytic Disinfection Using Titanium Dioxide: Spectrum and Mechanism of Antimicrobial Activity." Applied Microbiology Biotechnology 90: 1847-68.

[32] Cheigh, C. I., Park, M. H., Chung, M. S., Shin, J. K., and Park, Y. S. 2012. "Comparison of Intense Pulsed Lightand Ultraviolet (UVC)-Induced Cell Damage in Listeria Monocytogenes and Escherichia Coli O157:H7." Food Control 25: 654-9.

[33] Allion, A., Merlot, M., Boulangé-Petermann, L., Archambeau, C., Choquet, P., and Damasse, J.-M. 2007. "Thin Photocatalytic TiO2 Coatings: Impact on Bioadhesion and Cell Viability." Plasma Processes and Polymers 4: 374-9.

[34] Kasuga, T., Kondo, H., and Nogami, M. 2002. "Apatite Formation on $\mathrm{TiO}_{2}$ in Simulated Body Fluid." Journal of Crystal Growth 235: 235-40.

[35] Liou, J. W., and Chang, H. H. 2012. "Bactericidal Effects and Mechanisms of Visible Light-Responsive Titanium Dioxide Photocatalysts on Pathogenic Bacteria." Archivum Immunologiae et Therapiae Experimentalis 60 (4): 267-75.

[36] Kim, S., Ghafoor, K., Lee, J., Feng, M., Hong, J., and Lee, D. U. 2013. "Bacterial Inactivation in Water, DNA Strand Breaking, and Membrane Damage Induced by Ultraviolet-Assisted Titanium Dioxide Photocatalysis." Water Res. 47 (13): 4403-11.

[37] Lu, Z.-X., Zhou, L., Zhang, Z. L., Shi, W. L., Xie, Z. X., and Xie, H. Y. 2003. "Cell Damage Induced by Photocatalysis of $\mathrm{TiO}_{2}$ Thin Films." Langmuir 19: 8765-8.

[38] Verran, J., Packer, A., Kelly, P., and Whitehead, K. A. 2010. "Titanium-Coating of Stainless Steel as an Aid to Improved Cleanability." Int. J. Food Microbiol 141 Suppl 1: S134-9. 